\title{
Research on the Realization Path of Application-Oriented University
}

\author{
Ye Liu', Luan Shi², Li Liu' ${ }^{1}$ \\ ${ }^{1}$ Heilongjiang Bayi Agricultural University, Daqing, China \\ ${ }^{2}$ Heilongjiang Polytechnic, Haerbin, China \\ Email: byndly@126.com,27623373@qq.com
}

How to cite this paper: Liu, Y., Shi, L., \& Liu, L. (2020). Research on the Realization Path of Application-Oriented University. Open Journal of Social Sciences, 8, 387-393. https://doi.org/10.4236/jss.2020.86029

Received: May 25, 2020

Accepted: June 16, 2020

Published: June 19, 2020

Copyright (c) 2020 by author(s) and Scientific Research Publishing Inc. This work is licensed under the Creative Commons Attribution International License (CC BY 4.0).

http://creativecommons.org/licenses/by/4.0/

\begin{abstract}
The construction of Application-oriented Colleges and universities is a new mission entrusted to higher education by economic and social development. At present, there are a series of problems in the construction of application-oriented universities, such as inadequate understanding of the connotation of application-oriented universities, unclear development orientation, and ineffective evaluation methods. It can effectively strengthen the construction of Application-oriented Colleges and universities by inheriting and carrying forward the excellent tradition of running schools, defining the development goals and positioning, constructing the discipline and specialty system, and improving the connotation construction level of colleges and universities.
\end{abstract}

\section{Keywords}

Applied, Connotation System, Beidahuang Spirit

\section{Introduction}

It is a major decision-making deployment of the country to guide some local undergraduate universities to transform into application-oriented universities. Its connotation is to promote the universities to really transfer the ideas of running schools to serve the local economic and social development. Application-oriented universities are not only different from the traditional academic universities, but also different from Higher Vocational Colleges, which is the new mission given to higher education by the economic and social development. After more than 20 years of rapid development, China has established the largest higher education system in the world. The gross enrollment rate of higher education has reached $48.1 \%$. China is about to enter the popularization stage from 
the popularization stage of higher education. Under the background of popularization, how to effectively improve the quality of talent training, highlight the characteristics of running a school, and how to combine talent training, scientific research and social needs closely become a new proposition that colleges and universities need to answer (Pan \& Che, 2009).

\section{The Proposal of Application-Oriented University}

In recent years, the Application-oriented Education has aroused extensive attention in the field of education. Some universities have also carried out educational and teaching discussion activities for the Application-oriented Education and the construction of application-oriented universities. Some universities have also written the construction of Application-oriented Universities into the 13th five year development plan, which is to meet the needs of the development of the times and the development of higher education itself.

With the rapid development of economy and society, the structural contradiction of higher education has become more prominent, which has brought about serious problems of homogeneity. The characteristics of running a school are not obvious, the standards and quality of personnel training have not been improved, and the problems of difficult employment and low quality of employment have not been effectively alleviated.

In 2018, the National Conference on undergraduate education of colleges and universities in the new era was held to further deploy and implement the basic task of cultivating talents through morality, implement 40 higher education items in the new era, and draw important "construction drawings" for talent training in Colleges and universities. Chen Baosheng said that application-oriented universities should also strengthen first-class undergraduate education (Zhang, 2017). Building a strong country of higher education needs all kinds of talents. A large number of Application-oriented Colleges and universities in China should follow the development of the times and serve the local needs according to the school running tradition, location advantages and resource conditions, so as to develop their own characteristics and strive for the first class in the cultivation of application-oriented talents.

In 2019, Xi Jinping stressed at the national education conference that we should enhance the ability of education to serve the economic and social development, adjust and optimize the regional layout, discipline structure and professional setup of universities, establish and improve the dynamic adjustment mechanism of disciplines and specialties, promote the collaborative innovation of industry, University and research, and actively participate in the implementation of the innovation driven development strategy, focusing on cultivating innovative, compound and applied talents.

The above two important conferences put forward higher requirements for the construction of application-oriented undergraduate colleges, It also has a more clear guidance to effectively solve the problem of seeking perfection and homogeneity in higher education. It provides practical theoretical guidance for 
some colleges and universities that are ready to realize the transformation of application-oriented university, and has practical significance for further defining the development orientation and talent training orientation of colleges and universities.

\section{The Problems in the Construction of Applied Undergraduate Colleges and Universities}

\subsection{Inadequate Understanding of the Application-Oriented Connotation}

For a long time, scholars in the field of education have divided the types of school running from research type, teaching research type and teaching type, which also reflects the level of school running and the ecological niche of the level. Therefore, with the transformation and development of Application-oriented Colleges and universities, some colleges and universities do not have a deep understanding of the "application-oriented" concept (Xu, 2017). In terms of ideological understanding, there is a misunderstanding that "application-oriented colleges" are simply regarded as "Vocational Colleges", or that "application-oriented" is opposite to "Teaching and research-oriented".

\subsection{The Development Orientation Is Not Clear}

For a university, the orientation of development type is relatively fixed in a relatively long period, which is a description of development vision. Although some transformation colleges and universities have made clear the development orientation of application-oriented university, the development ideas, development goals, operation modes, personnel training modes, scientific research and other orientations matching the development orientation have not been adjusted with the transformation development (Li, 2016), and the level of connotation construction has not been significantly improved, which makes the transformation development become a slogan type transformation, and has not realized a substantial transformation Type construction.

\subsection{Connotation Construction and Application-Oriented Construction Are Not Synchronized}

The construction of application-oriented university is to rely on their own school running characteristics and improve the service to the local economic and social development. However, in the process of transformation, some colleges and universities are not in a fast pace of reform in school local cooperation, school enterprise cooperation, teachers' team construction, talent training program and curriculum system reform, school governance structure and other aspects, which fails to keep pace with the application-oriented construction.

\subsection{The Targeted Evaluation Method Has Not Been Effectively Established}

With the deep development of the transformation and reform of colleges and 
universities, some colleges and universities are actively exploring the construction of transformation and development, but in the process of development, restricted by the policy system, the traditional way of appropriation and the traditional evaluation system, the reform efforts need to be further strengthened.

\section{The Construction Path of Application-Oriented University}

\subsection{Truly Grasp the Essence of Application-Oriented Construction and Reach a Consensus on Development}

Consensus is the driving force for development. Only when the majority of teachers and workers have a clear understanding of the application-oriented construction and reach a consensus on the largest range of transformation and development, can they form a joint force and get twice the result with half the effort. For example, Heilongjiang Bayi Agricultural Reclamation University has reached a consensus on the transformation and development of application-oriented undergraduate universities among teachers and students through the education and teaching discussion activities. It is recognized that the transformation and development of Application-oriented Undergraduate Universities and teaching and research-oriented universities are not changes in the level of school running, but changes in different dimensions, both of which need high-level development. The differences are the key points of school running, governance system, governance structure, etc. The adjustment is to highlight the characteristics of the school and realize the differential development. In order to achieve high-level development, we must go out of the ivory tower, integrate with local governments, enterprises and industries in a deeper level, effectively improve the ability to serve regional economic development, and truly make contribution for development come true (Yao, 2016).

\subsection{Inherit and Carry Forward the Excellent School Running Tradition}

Generally, the application-oriented colleges and universities have inextricable historical origins with local enterprises or industries, and have condensed and formed certain school running characteristics and relatively distinct culture. How to carry forward the excellent school running spirit and culture in the transformation and development is a problem that colleges and universities need to study in depth (Zong, 2013). For example, Heilongjiang Bayi Agricultural Reclamation University and Heilongjiang Agricultural Reclamation co-exist and share the same origin and prosperity. Over the past 60 years, it has provided all kinds of talents and practical advanced technologies for the development and construction of Beidahuang. With the deepening of the reform of agricultural reclamation, how to expand the new connotation of Beidahuang spirit and create a modern corporate culture on the premise of inheriting and developing Beidahuang spirit is the integration development of both schools' and enterprises' strong pull and power of collaborative innovation. 


\subsection{Make Clear the Development Goal and Orientation in Combination with the Requirements of Application-Oriented Transformation}

Application-oriented colleges and universities more emphasize the service, the specific service-oriented, in a certain sense can become the school characteristics, but its core is the level of service and effectiveness. The construction of Application-oriented Colleges and universities is to focus on serving the economic and social development. Therefore, it is necessary to adjust the school running objectives, school running orientation, talent training orientation and mode, scientific research orientation, service-oriented orientation, etc., to really transfer the school running mode to the deep integration of production and education, the comprehensive cooperation between schools and enterprises, and to really transfer the talent training focus to the application-oriented technical and skilled talents Turn to enhancing students' ability of employment and entrepreneurship (Chen, 2013).

\subsection{Build a Discipline and Professional System Matching the Application-Oriented Construction}

The application-oriented undergraduate university is to provide applied talents, applied science and technology, and scientific and technological achievements for regional economic and social development. Therefore, the application-oriented university should comprehensively and deeply analyze the demand of social development and industrial development for talents and science and technology, Then adjust the structure of disciplines and specialties, set up the direction of specialties flexibly, adjust the personnel training mode in time, reform the personnel training program, add practice practice links, improve students' practical ability and innovation and creation ability, and train applied innovative talents for social development ( $\mathrm{Li}, 2012)$. At the same time, according to the needs of personnel training, we should increase the construction of double teacher teachers, improve the experimental practice ability of teachers, and ensure close connection with social and industrial development.

\subsection{Improve the Connotation Construction Level of Colleges and Universities}

Although the connotation construction has been widely written into the school constitution and development plan, it is the pain point of the development of colleges and universities to put the connotation construction in practice. The application-oriented colleges and universities focus on the integration of industry and education and the cooperation between schools and enterprises, emphasizing the service of social development and industrial development (Zhao, 2012). No matter the service of society or the service industry, efforts should be made to produce highlights and create models, but in the final analysis, it depends on the connotation construction of the school, especially the level of discipline construction. There is no high-level research team, no high-level research 
platform, no important scientific research achievements that can be converted into actual benefits, no high-level service. Therefore, condensing the characteristics of running a school is not only to "write it out", but more importantly to "make it out".

\subsection{Actively Adjust the Application-Oriented University Evaluation System}

For a long time, the national evaluation of colleges and universities has become the baton of the development and construction of colleges and universities. With the construction of Application-oriented Colleges and universities, the focus of talent training and scientific research in Colleges and universities will inevitably change from basic to practical, and talent training will change from theory oriented to coordinated development of theory and practice (Wang \& Wang, 2019). Scientific research will also change from basic research to applied research. Therefore, it is not completely accurate to evaluate the running situation of Application-oriented Universities with the traditional evaluation system, so it is necessary to build a coordinated evaluation system with the construction of Application-oriented Universities in time.

Since 2015, with the "The guiding opinions on guiding the transformation of some local ordinary colleges and universities into application-oriented universities" issued, the transformation and construction of application-oriented universities has gradually entered a good situation, and the structural spear shield of talent training and economic and social needs has been alleviated, but the governance structure, discipline and professional system, curriculum design and teacher structure of universities have been relieved It needs all-round and systematic design and reform, which needs to be explored and improved gradually in the process of practical operation.

\section{Funding}

Heilongjiang Bayi Agricultural University (CN) (Award Number: 2041080001). Teaching reform project of higher education in Heilongjiang Province (CN) (Award Number: GJZ201301072).

\section{Conflicts of Interest}

The authors declare no conflicts of interest regarding the publication of this paper.

\section{References}

Chen, Y. Q. (2013). Path Exploration of Application-Oriented Universities Serving Local Economic Transformation and Upgrading-Taking Zhejiang University of Science and Technology as an Example. Higher Education Research, 34, 43-47.

Li, J. (2016). Exploration of Applied Undergraduate Social Practice Mode. Jiangsu Education, No. 60, 72.

Li, R. S. (2012). Exploration on the Reform of Applied Undergraduate Talent Training 
Mode-Taking the " 211 " Talent Training Mode of Hubei University of Arts and Science as an Example. Higher Education Research, 33, 65-70.

Pan, M. Y., \& Che, R. S. (2009). On the Positioning of Application-Oriented University. Higher Education Research, 30, 35-38.

Wang, G. Y., \& Wang, M. M. (2019). Logical Thinking and Realization Path of Application-Oriented Personnel Training in Local Universities. China Higher Education, No. 7, 34-36

$\mathrm{Xu}, \mathrm{L}$. Q. (2017). Design Idea and Implementation Path of Local Applied Undergraduate Training Standard. Higher Education Research, 38, 81-85.

Yao, J. H. (2016). Analysis of the Characteristics of the Relationship between German Applied Technology University and the Government. Higher Education Research, 37, 96-104.

Zhao, H. F. (2012). Business Talent Training Mode of Applied Undergraduate Colleges. Higher Education Research, 33, 88-92.

Zhang, H. S. (2017). Construction of Professional Degree Points in New Undergraduate Colleges and Universities under the Background of Transformation: Basic Logic and Implementation Path. Coal Higher Education, 35, 46-52.

Zong, Y. X. (2013). Positioning and Realization Path of New Local Application-Oriented Universities in Collaborative Innovation System. Journal of Langfang Normal University (Social Science Edition), 29, 117-120. 